\title{
Wspomnienie o prof. dr. hab. Henryku Terelaku (1937-2015)
}

W dniu 30 września 2015 roku zmarł profesor doktor habilitowany Henryk Terelak, długoletni pracownik naukowy Instytutu Uprawy Nawożenia i Gleboznawstwa(IUNG) w Puławach, doskonały gleboznawca, ekspert z zakresu chemii gleb i ochrony środowiska glebowego.

Profesor doktor habilitowany Henryk Terelak urodził się 15 września 1937 roku w Rykoszynie (obecne woj. świętokrzyskie). W 1956 roku rozpoczął studia na $\mathrm{Wy}$ dziale Rolniczym Wyższej Szkoły Rolniczej (WSR) w Lublinie. W 1961 roku obronił pracę magisterską pt. Wptyw dodatku torfu surowego na rozkład zielonej masy roślin motylkowych, która wykonał w Katedrze Chemii

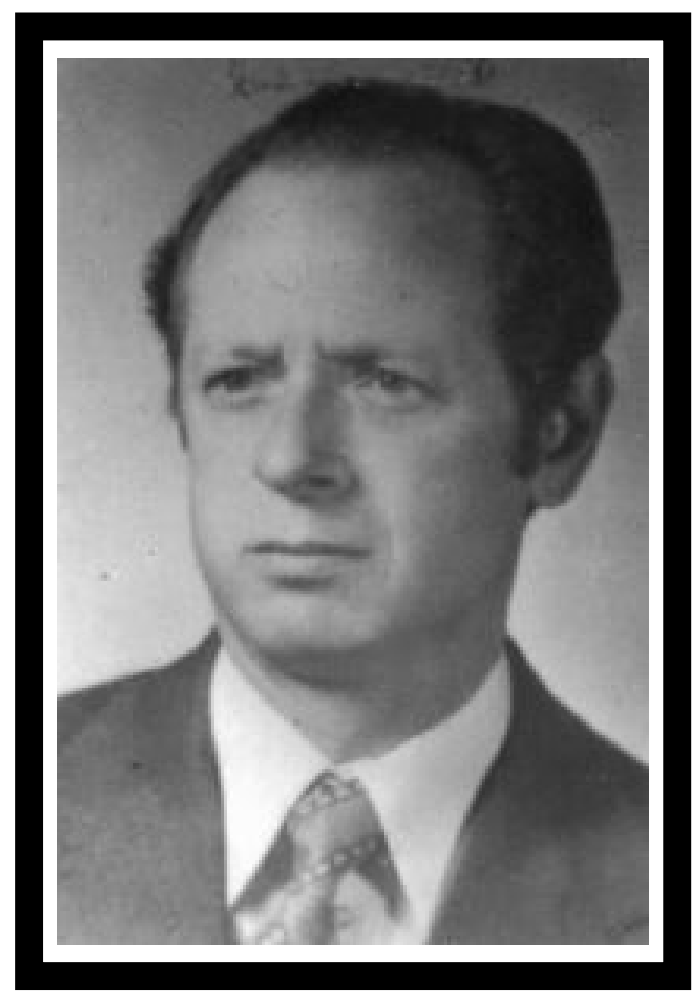

ściami a przydatnością rolniczą gleb; 2) dynamiką i przemianami form potasu $\mathrm{w}$ glebie w zależności od poziomu nawożenia tym składnikiem; 3) ochroną i rekultywacją gleb degradowanych; 4) oceną stanu zanieczyszczenia gleb substancjami toksycznymi; 5) wpływem nawożenia na zawartość składników mineralnych w wodach glebowo-gruntowych i powierzchniowych.

Prof. dr hab. H. Terelak był człowiekiem niezwykle pracowitym. Pozostawił po sobie obszerny i cenny dorobek naukowy. Był autorem lub współautorem ponad 300 publikacji, komunikatów, doniesień i oryginalnych opracowań kartograficznych, 50 raportów i ekspertyz oraz 15 Rolnej WSR w Lublinie. W tym samym roku podjął pracę w Zakładzie Gleboznawstwa i Kartografii Gleb IUNG, w Pracowni Chemii Gleb. W 1970 roku uzyskał stopień naukowy doktora nauk rolniczych za pracę pt. Zależność pomiędzy właściwościami przyrodniczymi a rolnicza przydatnościa gleb. W 1985 roku otrzymał stopień naukowy doktora habilitowanego nauk rolniczych w zakresie chemii gleb i nawożenia na podstawie oceny ogólnego dorobku naukowego i przedłożonej rozprawy habilitacyjnej nt. Ksztattowanie się glebowych wskaźników zaopatrzenia roślin $w$ potas $w$ zależności od poziomu nawożenia tym składnikiem i gatunku gleby. W 1992 roku uzyskał tytuł naukowy profesora nauk rolniczych.

Wśród osiagnięć naukowych prof. dr. hab. H. Terelaka na szczególną uwagę zasługują prace związane z: 1) oceną właściwości fizykochemicznych gleb oraz określeniem związków między tymi właściwo- opracowań książkowych i monograficznych, w tym Studium ochrony, rekultywacji i zagospodarowania użytków rolnych w strefie oddziaływania projektowanego Kombinatu Paliwowo-Energetycznego Betchatów (1972); Ochrona i rekultywacja gleb (1978); Właściwości chemiczne gleb uprawnych Polski (1979); Zawartość form siarki w glebach mineralnych Polski (1988); Pierwiastki śladowe (Cd, Cu, Ni, Pb i Zn) w glebach użytków rolnych Polski (2000); Gleboznawstwo ekologiczne (2002) oraz czterech opracowań z cyklu Monitoring chemizmu gleb ornych Polski (1999, 2000, 2008, 2012). Prof. dr hab. H. Terelak był promotorem trzech przewodów doktorskich, recenzentem m.in. sześciu prac doktorskich oraz dziewięciu rozpraw habilitacyjnych i dorobku na stopień naukowy doktora habilitowanego.

Ogromna wiedza i doświadczenie Pana Profesora sprawiło, że był koordynatorem i uczestnikiem wielu 
projektów międzynarodowych i krajowych, m.in.: Zintegrowany System Informacji o rolniczej przestrzeni produkcyjnej Polski i Opracowanie bazy danych SOTER do mapy 1:2,5 mln (1998-1999), Wtaściwości gleb użytków rolnych i zawartość pierwiastków toksycznych w glebach i roślinach (1992-1998), a do 2007 roku koordynatorem jednego z bardzo ważnych programów krajowych: Monitoring chemizmu gleb ornych Polski. Program ten jest kontynuowany do chwili obecnej.

Prof. dr hab. H. Terelak aktywnie uczestniczył w pracach komitetów redakcyjnych czasopism naukowych, m.in.: Pamiętnika Puławskiego (1991-2010), Roczników Gleboznawczych (2000-2011) oraz Polish Journal of Soil Science (2003-2011). Pełnił funkcję członka komitetów naukowych licznych konferencji krajowych i zagranicznych. Przez wiele lat prowadził wykłady z zakresu gleboznawstwa, klasyfikacji bonitacyjnej gleb oraz ochrony środowiska dla uczestników Studium Podyplomowego z zakresu „Gleboznawstwo, klasyfikacja i kartografia gleb” oraz Studium Doktoranckiego przy IUNG.

Prof. dr hab. H. Terelak łączył gruntowną wiedzę teoretyczną z praktyką zdobytą w kraju i za granicą. W latach 1965-1966 odbył roczny staż naukowy w Stanach Zjednoczonych Ameryki, w pracowni Chemii Gleb Wydziału Rolnego Pensylvania State University, a w latach 1975-1976 pracował jako specjalista PHZ „Polservice” w międzynarodowym zespole organizującym wielkoobszarowe gospodarstwa rolne w półpustynnym obszarze Jovein (Iran). W trakcie pobytu w Iranie odpowiadał za problemy nawożenia gleb i ocenę ich przydatności do uprawy różnych roślin. W latach 1981-1983 pracował w Laosie jako ekspert FAO koordynując projekt Soil Inventory and Fertilization. Organizował od podstaw laboratorium chemiczno-rolnicze i prowadził szkolenia w zakresie analiz chemicznych gleb i materiału roślinnego.

Kariera zawodowa prof. dr. hab. H. Terelaka była związana z IUNG w Puławach. W Instytucie pełnił wiele odpowiedzialnych funkcji. W latach 1986-1993 był zastępcą Dyrektora IUNG do spraw naukowobadawczych, a w okresie 1993-1998 kierownikiem Zakładu Gleboznawstwa i Ochrony Gruntów. Pełnił funkcję zastępcy przewodniczącego Rady Naukowej (2003-2007) oraz Przewodniczącego Komisji ds. Przewodów Doktorskich i Rozwoju Kadry. W latach 1996-2010 był członkiem Zespołu Koordynacyjnego Dyrektora IUNG ds. realizacji programów badawczych Podstawy zrównoważonego gospodarowania $i$ ochrony rolniczej przestrzeni produkcyjnej Polski oraz Zrównoważony rozwój produkcji roślinnej i ksztatto- wanie przestrzeni rolniczej Polski. W latach 19962001 był koordynatorem Obszaru Badawczego Biologiczne, chemiczne i fizyczne podstawy żyzności $i$ ochrony gleb. W dowód uznania został nagrodzony Medalem Honorowym „Instytut Uprawy Nawożenia i Gleboznawstwa w Służbie Rolnictwa" (2007).

Pan Profesor cieszył się ogromnym szacunkiem różnych środowisk naukowych w kraju. Był członkiem Komitetu Inżynierii Środowiska PAN (19921995), Komitetu Gleboznawstwa i Chemii Rolnej PAN (1992-2010), Lubelskiego Towarzystwa Naukowego (od 1997 roku) oraz Komisji Rolnictwa Oddziału PAN w Lublinie (2001-2010). W latach 20012007 był członkiem Krajowego Zespołu ds. współpracy z Europejską Agencją Środowiska (EIONET). W latach 2000-2005 został powołany przez Ministra Rolnictwa i Rozwoju Wsi na członka rady monitoringu w zakresie jakości gleb, roślin, produktów rolniczych i spożywczych.

Prof. dr hab. H. Terelak należał do wielu zagranicznych i krajowych towarzystw naukowych m.in. American Society of Agronomy i Indian Soil Science Society, New York Academy of Science, American Association for the Advancement of Science i Międzynarodowej Unii Towarzystw Gleboznawczych. Od 1961 roku do śmierci Pan Profesor był członkiem Polskiego Towarzystwa Gleboznawczego (PTG). Do 2011 roku bardzo czynnie uczestniczył w pracach zarządu Oddziału PTG w Puławach organizując konferencje terenowe i wykłady. W latach 1974-1979 oraz 1995-1999 był przewodniczącym, a przez kadencje 1971-1973 oraz 2003-2011 wiceprzewodniczącym Oddziału Puławskiego PTG. Od roku 1983 przez kolejnych dwadzieścia lat był członkiem Zarządu Głównego PTG i odpowiadał za współpracę z Ministerstwem Rolnictwa (1983-2003) oraz kierował Działem Użytkowania Gleb (2003-2011). W 1978 roku Pan Profesor otrzymał „Złotą Odznakę Polskiego Towarzystwa Gleboznawczego", a w 2012 roku z okazji obchodów 75-lecia działalności Towarzystwa, w uznaniu za zasługi dla PTG, został wyróżniony medalem pamiątkowym.

Prof. dr hab. H. Terelak był autorytetem w wielu dziedzinach związanych z gleboznawstwem. W uznaniu Jego osiagnieć i zasług w pracy naukowej i na rzecz praktyki rolniczej został sześciokrotnie wyróżniony nagrodą Dyrektora IUNG, a w 1988 roku otrzymał zespołową nagrodę Dyrektora Instytutu Ochrony Środowiska. Był laureatem zespołowej nagrody im. prof. W. Goetla (1988), nagrody Rektora Akademii Rolniczo-Technicznej (ART) w Olsztynie (1992) oraz trzykrotnie zespołowej nagrody Ministra Rolnictwa $(1988,1995$ i 2013). Za całokształt pracy na- 
ukowej, współpracę z praktyką i działalność społeczną Pan Profesor otrzymał wiele odznaczeń resortowych oraz państwowych, w tym odznakę ,Zasłużony Pracownik Rolnictwa” (1975), „Złotą Odznakę dla Ochrony Środowiska i Gospodarki Wodnej (1995), „Złoty Krzyż Zasługi” (1980) i „Krzyż Kawalerski Orderu Odrodzenia Polski” (2000).

Ze społeczności IUNG w Puławach odszedł człowiek bardzo pracowity i konsekwentny w działaniach, wielce oddany pracy naukowej na rzecz rolnictwa, dbający o dobre imię i wizerunek IUNG oraz Zakładu Naukowego, w którym pracował. Profesor H. Terelak cieszył się ogromnym szacunkiem współpracowników, służąc im zawsze rada, pomocą i wsparciem. 30 września 2015 roku pożegnaliśmy znakomitego gleboznawcę, ale przede wszystkim Kolegę, który w naszej pamięci pozostawił wiele bardzo dobrych wspomnień.

CZEŚĆ JEGO PAMIĘCI!

\section{In the memory of Professor Henryk Terelak (1937-2015)}

The workers of the Institute of Soil Science and Plant Cultivation - State Research Institute in Puławy, Poland and the members of the Polish Society of Soil Science inform with the great grief, that Professor Henryk Terelak passed away on September 30, 2015 in Puławy.

His scientific career and professional life were linked with the Institute in Puławy, which he joined in 1961 and was working since 2011 . He obtained the $\mathrm{PhD}$ degree in 1970. In 1985 he became the associated professor. Since 1992 he has held the full professor position. Prof. H. Terelak was an expert in soil chemistry and protection of soil environment. His scientific achievements concerned: (1) evaluation of soil properties in relation to soil agricultural use; (2) dynamics and transformation of potassium in soils; (3) protection and reclamation of degraded soils; (4) assessment of contamination status of Polish agricultural soils and (5) the impact of fertilization on ground water quality. He was the coordinator and team member of international and Polish programs, lecturer and a member of editorial boards of scientific journals. He combined theoretical knowledge with practice gained during scientific internships in USA, Iran, and Laos. Prof. Terelak was the author and co-author of more than 300 publications, abstracts and original maps, 50 reports and expertises, 15 books and monographs.

Prof. Terelak was a member of numerous foreign and Polish scientific societies, e.g. New York Academy of Science, American Association for the Advancement of Science and the International Union of Soil Sciences. He was the member of the Main Board of the Polish Society of Soil Science and the chair of the Pulawy Branch of this society.

He was the vice-Head of the Institute of Soil Science and Plant Cultivation (1983-1993), the Head of the
Department of Soil Science and Land Protection (1993-1998), and one of the leading scientist creating research programmes of the Institute. His scientific achievements and work for agriculture has been awarded with numerous honors and prizes. The society of Institute of Soil Science and Plant Cultivation and colleagues from the Department of Soil Science and Plant Cultivation lost one of the best soil scientists and researcher who was highly recognized and respected. He left many very good memories behind.

The most important scientific publications, books, and monographs by Professor $\mathrm{H}$. Terelak are listed below. PL signature means that the original language of the article was Polish. Most of them have English abstract or summary.

1. Terelak H., Matelski R.P., 1967. Comparison of the results of organic matter content determination in soils by the Walkley-Black method and dry combustion. Pamiętnik Puławski, 30: 57-60 (PL).

2. Siuta J., Terelak H., 1969. The development of root system of hop in relation to soil properties. Polish Journal of Soil Science, 2: 163-170.

3. Baker B.E., Grube W.E., Terelak H., McGahen J.H., 1970. Chemical element concentration in leaves of double-cross corn hybrids as affected by stand densities and different rates of nitrogen. Soil Science, 5: 339-345.

4. Siuta J., Terelak H., 1970. Exchange capacity of soil horizons with a similar content of colloids. Polish Journal of Soil Science, 1: 53-5.

5. Terelak H., 1971.The relationship between properties and agricultural suitability of soils. Pamiętnik Puławski, 48: 41-71 (PL).

6. Pondel H., Terelak H., Terelak T., 1972. Chemical properties of different agricultural-soil complexes. Pamiętnik Puławski, 53, 59-98 (PL). 
7. Terelak H., 1973.The solubility and the fertilizing value of polyhalite as affected by the degree of crushing and calcination. Pamiętnik Puławski, 59, 39-52 (PL).

8. Terelak H., 1974. The agricultural suitability of soils against their natural properties. Nowe Rolnictwo, 8: 1-3 (PL).

9. Terelak H., Sadurski W., 1979. Influence of differentiated potassium fertilization level on statical and dynamical indices of the content of this element in soil. Roczniki Gleboznawcze - Soil Science Annual, 30(1): 125-135 (PL).

10. Terelak H., Żórawska B., 1979. Effect of brown coal ash and hard coal and peat furnace wastes on properties of light soils and yielding of crops. Roczniki Gleboznawcze - Soil Science Annual, 30(3): 109-122 (PL).

11. Terelak H., 1978. Model investigations on dynamics of potassium and some cations in soil under the fertilization effect. Roczniki Gleboznawcze - Soil Science Annual, 29(1): 27-39 (PL).

12. Terelak H., Karczewski A., 1977. Depth and chemical composition of ground waters in the region of the Mining and Energetic Works ,Bełchatów”. Roczniki Gleboznawcze - Soil Science Annual, 28(1): 3-14 (PL).

13. Pondel H., Terelak H., Sadurska S., 1978. Chemical composition of waters in Bystra drainage basin (Upland of Lublin). Pamiętnik Puławski, 70: 1-7 (PL).

14. Pondel H., Terelak H., 1981. Chemical composition of drainage waters as a basis for evaluation of mineral element losses by leaching out to the ground waters. Pamiętnik Puławski, 77: 149-168 (PL).

15. Terelak H., Fotyma M., 1986. Effect of potassium fertilization on the content of forms of this element in soils and their utilization by plants. Roczniki Gleboznawcze - Soil Science Annual, 37(1): 203-213 (PL).

16. Pondel H., Terelak H., 1986. Chemical composition of the rainfall and the ground waters in the vicinity of Puławy. Pamiętnik Puławski, 88: 5770 (PL).

17. Terelak H., 1987. Centent of organic carbon and textural fractions of the soils developed from flysh. Pamiętnik Puławski, 90: 27-36 (PL).

18. Terelak H., Sadurski W., 1981. Model investigations on the formation of some indices of the potassium content in soil depending on the potassium fertilizer and lime. Roczniki Gleboznawcze - Soil Science Annual, 32(2): 87-102 (PL).

19. Terelak H., Sadurski W., 1990. Changes of chemical properties of the soils in the vicinity of nitrogen fertilizer works at Puławy. Pamiętnik Puławski, 98, 185-199 (PL).

20. Teralak H., Witek T., 1993. Assessment of the degree of soil and plant contamination with heavy metals and sulfur - guidelines for agriculture. IUNG, Puławy, Seria P(53): 1-20 (PL).

21. Terelak H., Pondel H., 1993. Displacement of fertilizer elements from cultivated soils to the soilground and surface waters. Zesz. Probl. Post. Nauk Roln., 400: 15-22.

22. Teralak H., Motowicka-Terelak T., 1994. Chemical degradation and liming efficiency of soils contaminated with sulphur. Polish J. Soil Sc., 27: $37-$ 42.

23. Terelak H., Witek T., 1994. Past, present and future of soil survey in Poland. ITC and FAO Publication, 21: 104-107.

24. Fotyma M., Terelak H., 1994. Environmental challenges in Polish agriculture covering a main area of the Baltic Sea Basin. Marine Poll. Bull., 6-12: 455-463.

25. Terelak H., Motowicka-Terelak T., 1995.Residual effect of acid rain on the soil. Soil Sc. Agrochem. and Ecology, 1-6: 168-170.

26. Terelak H., Mańko P., 1995. Composition of atmospheric precipitation in the Puławy area, $\mathrm{Pa}$ miętnik Puławski, 106: 149-156 (PL).

27. Terelak H., Piotrowska M., Motowicka-Terelak T., Stuczyński T., Budzyńska K., 1995. The content of heavy metals and sulphur in Polish agricultural soils and their contamination with those elements. Zesz. Prob. Post. Nauk Roln., 418; 45-60 (PL).

28. Terelak H., Piotrowska M., Budzyńska K., 1995. The contamination status of Polish soils with cadmium. A map at a scale of 1: 500000 . IUNG, Puławy (PL).

29. Terelak H., Piotrowska M., Budzyńska K., Pietruch C., Wróblewska E., 1995. The contamination status of Polish soils with copper. A map at a scale of 1:500 000. IUNG, Puławy. (PL)

30. Terelak H., Piotrowska M., Budzyńska K., Pietruch C., 1995. The contamination status of Polish soils with heavy metals. A map at a scale of 1:1 000 000. Wyd. Okręgowe Przedsiębiorstwo Geodezyjno-Kartograficzne w Białymstoku (PL).

31. Dutka S., Piotrowska M., Terelak H., 1996. Transfer of cadmium, lead and zink from industrially contaminated soil to crop plants: A field study. Environm. Pollution, 94(2): 181-188.

32. Terelak H., Motowicka-Terelak T., Stuczyński T., 1996. Direct and residual effects of sulphur pollution on the acidity of a loamy soil. Appl. Geochem, 1-2: 371-375. 
33. Terelak H., Motowicka-Terelak T., Stuczyński T., 2000. The principles and scope of soil properties monitoring programme and the current state of Polish soil environment. Nawozy i Nawożenie, 3(4): 178-199 (PL).

34. Terelak H., Motowicka-Terelak T., 2001. Sulphur content in dandelion (Taraxacum officinale) as an indicator of threat to agroecosystems. Acta Agroph., 51: 165-170.

35. Lipiński W., Terelak H., Stuczyński T., 2001. Concentration of heavy metals in the agricultural soils of the Lublin region and Poland. Acta Agroph., 51: 243-253.

36. Terelak H., Motowicka-Terelak T., Wróblewska E., Gawrysiak L., Pietruch C., 2001. The content of organic matter in Polish agricultural soils. A numeric soil map of Poland at a scale of 1:500 000. IUNG, Puławy (PL).

37. Terelak H., Motowicka-Terelak T., Wróblewska E., Gawrysiak L., Pietruch C., 2001. The reaction of Polish agricultutral soils. A numeric soil map of Poland at a scale of 1:500 000. IUNG, Puławy (PL).

38. Motowicka-Terelak T., Terelak H., 2002. Ecological soil science. Wyd. Wszechnicy Mazurskiej, pp 168 (PL).

39. Terelak H., Motowicka-Terelak T., MaliszewskaKordybach B., Pietruch C., 2002. Monitoring of
Polish arable soils - programme and results. Biblioteka Monitoringu Środowiska, Warszawa, pp. 146 (PL).

40. Oleszek W., Terelak H., Maliszewska-Kordybach B., Kukuła S., 2003. Food and agroproduct contamination monitoring in Poland. Pol. J. Env. Stud., 12(3): 261-268.

41. Lipiński W., Terelak H., Motowicka-Terelak T., 2003. Suggestion for limiting values of sulphate sulphur content in mineral soils for fertilization advisory needs. Roczniki Gleboznawcze - Soil Science Annual, 54(3): 79-84 (PL).

42. Tujaka A., Terelak H., Pietruch C., 2004. Lead content in humic horizons of agricultural soils of Poland. Roczniki Gleboznawcze - Soil Science Annual, 55(3): 213-219 (PL).

43. Noworolnik K., Terelak H., 2006. The effect of soil properties on grain and protein yields of spring barley, oats and their mixture. Roczniki Gleboznawcze - Soil Science Annual, 57(3/4): 72-79 (PL).

44. Tujaka A., Terelak H., 2010. Water and sludge management in Poland, Roczniki Gleboznawcze - Soil Science Annual, 61(1): 67-76 (PL).

45. Tujaka A., Terelak H., 2012. The balance of Phosphorus in the agriculture of Poland. Pol. Journal of Agronomy, 9: 28-33. 